\title{
Nucleotide Depletion Due to Reactive Oxygen Metabolites in Endothelial Cells: Effects of Antioxidants and 3-Aminobenzamide
}

\author{
T. KRISTIINA AALTO AND KARI O. RAIVIO \\ Children's Hospital, University of Helsinki. SF-00290 Helsinki, Finland
}

\begin{abstract}
Reactive oxygen metabolites have an important role in ischemia-reperfusion injury. One of the sources of reactive oxygen metabolites is xanthine oxidase, which is present in several tissues but is also released into the circulation after ischemia. We studied the effect of several potentially protective compounds on adenine nucleotide depletion induced by extracellular xanthine oxidase and hypoxanthine, in concentrations relevant to human pathophysiology. In umbilical vein endothelial cells prelabeled with ${ }^{14} \mathrm{C}$-adenine, cellular adenine nucleotides retained 64 $\pm 9 \%$ of the initial radioactivity over a 4 -h incubation with culture medium (controls), whereas in the presence of xanthine oxidase $(80 \mathrm{mU} / \mathrm{mL})$ and hypoxanthine $(100$ $\mu \mathrm{M}$ ), only $3 \pm 4 \%$ of radioactivity remained in cellular nucleotides, the rest appearing in catabolic products in the medium. Glutathione and 3-aminobenzamide, an inhibitor of poly-ADP-ribose polymerase, partly prevented the nucleotide depletion (adenine nucleotide radioactivity $15 \pm$ $6 \%$ to $33 \pm 13 \%$ of total), but scavengers of the hydroxyl radical, dimethylthiourea and DMSO, as well as vitamins $\mathrm{E}$ and $\mathrm{C}$, were without effect. Superoxide dismutase prevented the leakage of nucleotides into the culture medium but not intracellular nucleotide catabolism, whereas the latter process was decreased by catalase, consistent with predominant effects of superoxide and hydrogen peroxide at the cell membrane and interior, respectively. (Pediatr Res 34: 572-576, 1993)
\end{abstract}

Abbreviations

3-ABA, 3-aminobenzamide

CAT, catalase

DMTU, dimethylthiourea

GSH, glutathione

ROM, reactive oxygen metabolites

SOD, superoxide dismutase

XO, xanthine oxidase

LDH, lactate dehydrogenase

ROM have been ascribed a significant role in ischemia-reperfusion injury (1). Free radicals can cause enzyme inactivation and DNA strand breaks, as well as protein and lipid damage leading to alterations in membrane structures (2). An important source of these radicals is the enzyme XO (EC 1.1.3.22), which is generated in ischemic tissue from its physiologically occurring form, xanthine dehydrogenase. At the same time, the substrate

Received October 6, 1992; accepted June 22, 1993.

Correspondence: Kristiina Aalto. M.D. Children's Hospital, University of Helsinki, Stenbäckinkatu 11, SF-00290 Helsinki. Finland.

Supported by the Foundation for Pediatric Research in Finland. The Academy of Finland, the Sigrid Juselius Foundation, and Farmos Research Foundation. of XO, hypoxanthine, accumulates and upon reperfusion is converted into xanthine and uric acid, with reactive oxygen species as by-products (3-5). In the neonatal period, and especially in preterm infants, a number of important clinical problems have been ascribed to ROM $(6,7)$.

In man, XO activity has been found mainly in the liver, kidney, and intestine (8). XO may be released from perfused rat liver during and after ischemia (9), and significant XO activity was found in plasma after release of tourniquet-induced ischemia in patients undergoing surgery of the upper extremity (10). Another extracellular source of free radicals is granulocytes (11), which accumulate in postischemic tissue. Although many cell types, e.g. epithelial cells, fibroblasts, and hepatocytes, may be damaged by ROM (12), the endothelial cell is a prime target as shown by microscopic studies in several models of ischemiareperfusion injury $(13,14)$. Also, granulocytes attach primarily to endothelial cells in tissues after ischemia.

We have previously characterized the effects of extracellular $\mathrm{XO}$ and hypoxanthine on human umbilical vein endothelial cells, using depletion of radioactive adenine nucleotides from prelabeled cells as a sensitive index of cell damage. In this study, we tested several compounds previously shown to prevent or modify ROM-induced cell damage with respect to their ability to prevent nucleotide depletion induced by $\mathrm{XO}$ and hypoxanthine. The concentrations of the effectors were in the range encountered in clinical situations, and those of the protective compounds were in the range achievable in vivo.

\section{MATERIALS AND METHODS}

Cell culture and labeling. Endothelial cells were cultured from human umbilical veins as described previously (15) and used before the 6 th passage. Briefly, the cells were detached with $0.2 \%$ collagenase (Worthington Biochemical Corporation, Freehold, $\mathrm{NJ}$ ) and grown to confluency in $25-\mathrm{cm}^{2}$ culture flasks (Nunc, Roskilde, Denmark) coated with $0.2 \%$ gelatin (Mcrck, Darmstadt, Germany) in F-10 medium (Gibco Europe, Paisley, UK) containing $20 \%$ pooled sterilized human serum (Finnish Red Cross, Helsinki, Finland) at $37^{\circ} \mathrm{C}\left(5 \% \mathrm{CO}_{2}-95 \%\right.$ air $)$. For the experiments, cells were transferred to gelatin-coated wells with a diameter of $1.5 \mathrm{~cm}$ (Multidish, Nunc) and cultured in F-10 medium containing $20 \%$ human serum until confluent. The cells were then prelabeled with ${ }^{14} \mathrm{C}$-adenine (sp act $51-55 \mathrm{mCi} / \mathrm{mmol}$; Amersham International, Amersham, UK), final concentration $0.1 \mathrm{mM}$. After $16-18 \mathrm{~h}$, the labeled medium was removed and the cells were washed three times with purine-free RPMI 1640 medium (Gibco Europe).

Incubation with test compounds. For actual experiments, serum-free RPMI 1640 medium was added to each multidish well, followed by either 5,10 , or $15 \mathrm{mM}$ GSH (Merck); 300 or $600 \mathrm{IU} / \mathrm{mL}(220 \mu \mathrm{g} / \mathrm{mL})$ SOD (Cu,Zn-SOD, EC 1.15.1.1, Sigma Chemical Company, St. Louis, MO); 300 or $600 \mathrm{IU} / \mathrm{mL}(60 \mu \mathrm{g} /$ $\mathrm{mL}$ ) CAT (Sigma, EC 1.11.1.6); SOD and CAT; 5,10 , or 15 
mM DMTU (Aldrich-Chemie, Steinheim, Germany); 5 or 10 mM DMSO (Merck); 50 or $100 \mu \mathrm{M} \alpha$-tocopherol (Sigma); 100 $\mu \mathrm{M}$ or $10 \mathrm{mM}$ ascorbic acid (Merck); or 5,10 , or $15 \mathrm{mM} \mathrm{3-ABA}$ (Sigma). Then, after $15 \mathrm{~min}$ of preincubation, $100 \mu \mathrm{M}$ unlabeled hypoxanthine (Sigma) and $80 \mathrm{mU} / \mathrm{mL}$ XO (Bochringer Mannheim $\mathrm{GmbH}$, Penzberg. Germany) were added. These concentrations were previously found to result in significant depletion of cellular adenine nucleotides (15), which was considered a suitable basis for assessing the effects of scavengers. The commercial XO preparation has protease contamination, but we have previously shown that the cellular nucleotide depletion is not due to the protease activity (15). In some experiments, we also used a protease-free commercial XO preparation (Biozyme Laboratories Ltd., Blaenavon, UK). After incubation at $37^{\circ} \mathrm{C}$ $\left(5 \% \mathrm{CO}_{2}, 95 \%\right.$ air) for $4 \mathrm{~h}$, the medium was removed and frozen, and the cells were cooled on ice, extracted twice with $100 \mu \mathrm{L}$ of ice-cold $0.4 \mathrm{M}$ perchloric acid, and frozen at $-20^{\circ} \mathrm{C}$ until analysis.

Analysis of purine compounds. Nucleotides in the cell extracts and medium and their catabolic products (hypoxanthine, xanthine, uric acid) in the medium were separated and their radioactivities measured by thin-layer chromatography as previously described (15).

${ }^{51} \mathrm{Cr}$-release from endothelial cells. To obtain an independent assessment of free radical damage. cells were incubated overnight with $1 \mu \mathrm{Ci} / \mathrm{mL}{ }^{51} \mathrm{Cr}$ (sodium chromate. Amersham International), washed three times, and incubated for $4 \mathrm{~h}$ with $\mathrm{XO}$ and hypoxanthine in the presence and absence of $5 \mathrm{mM} \mathrm{GSH}$. Release of ${ }^{51} \mathrm{Cr}$ was calculated in terms of $\mathrm{cpm}$ released from the test cells into the medium as percent of the maximum released from cells treated with $0.4 \mathrm{M}$ perchloric acid.

Expression of results and statistical methods. ${ }^{14} \mathrm{C}$-adenine labeled mainly the adenine nucleotide pool; other purine nucleotides contained $3 \pm 1 \%$ and nucleic acids $11 \pm 5 \%$ of the radioactivity taken up by the cells $(n=8)$. Because the latter were unaltered in the course of the experiments, the results are expressed as the percent distribution of radioactivity between adenine nucleotides (cells and medium separately) and their catabolic products (hypoxanthine, xanthine, uric acid). The interassay variation was $5 \%$ in thin-layer chromatography. Previous work with different types of cultured cells has shown that there is no difference between the metabolism of ${ }^{14} \mathrm{C}$-labeled and unlabeled nucleotides (16).

Experiments were performed in duplicate at least twice. BMDP statistical software was used for data analysis (17). Comparisons between groups were done using the nonparametric Mann-Whitney $\mathrm{U}$ test and $p<0.05$ was considered significant. Results are expressed as means $\pm \mathrm{SD}$.

\section{RESULTS}

Nucleotide depletion by $\mathrm{XO}$ and hypoxanthine. In the presence of $100 \mu \mathrm{M}$ hypoxanthine, $80 \mathrm{mU} / \mathrm{mL}$ XO caused a profound nucleotide depletion: in $4 \mathrm{~h}$, cellular adenine nucleotides decreased to $3 \pm 4 \%$ (control $64 \pm 9 \%$ ) and catabolic products in the medium increased to $71 \pm 6 \%$; over $95 \%$ of the catabolic products were uric acid and xanthine (control $32 \pm 7 \%$, over $90 \%$ was hypoxanthine) (Fig. 1). After control incubations, an average of $5 \pm 4 \%$ (Fig. 1) of the total radioactivity were in nucleotides in the medium. Treatment with hypoxanthine and $\mathrm{XO}$ increased this to $23 \pm 10 \%$ (Fig. 1). However, because of significant ectonucleotidase activity on endothelial cells (18), part of the nucleotides released may appear as catabolic products under the present experimental conditions.

$G S H$. GSH alone had no effect on endothelial cell adenine nucleotides (data not shown). In incubations with XO and hypoxanthine, there was a dose-dependent but only partial prevention of cellular nucleotide depletion (Fig. 1). Concomitantly, there was a decrease in the radioactivity in the catabolic products but no significant change in nucleotides in the medium.

To test the effects of GSH with another assay, release of ${ }^{51} \mathrm{Cr}$ from prelabeled cells was measured. $\mathrm{XO}$ and hypoxanthine together increased the ${ }^{51} \mathrm{Cr}$ release up to $71 \pm 14 \%$ (spontaneous release in the control cells, $19 \pm 6 \%$ ), and incubation with both $\mathrm{XO}$ and hypoxanthine together with $5 \mathrm{mM}$ GSH decreased the release to the level of $50 \pm 11 \%$ (Fig. 2). Thus, exposure to the superoxide-generating system and the cytoprotective effect of GSH are reflected similarly in our nucleotide depletion assay and chromium release.

Antioxidant enzlmes. SOD alone had no effect on cellular adenine nucleotides, but it prevented the leakage of nucleotides into the medium induced by $\mathrm{XO}$ and hypoxanthine. Intracellular nucleotides decreased to $11 \pm 1 \%$ of the total radioactivity taken up by the cells compared with $10 \pm 1 \%$ in the absence of SOD (Fig. 3), but nucleotides in the medium decreased to $7 \pm 1 \%$ compared with $11 \pm 2 \%$ in the absence of SOD. CAT alone had a marked protective effect on the depletion of cellular nucleotides, which remained at the level of $38 \pm 3 \%$ of total radioactivity, and a matching decrease in catabolic products was observed (Fig. 3). However, CAT had no significant effect on the leakage of nucleotides into the medium (Fig. 3). When both SOD and CAT were present in the medium together with both $\mathrm{XO}$ and hypoxanthine, no additive protective effect was seen (Fig. 3), inasmuch as the decreased nucleotide leakage and decreased intracellular catabolism were in the range observed with either enzyme alone.

Smaller amounts of these enzymes, that is $300 \mathrm{IU} / \mathrm{mL}$, had no effect on the nucleotide depletion due to the combination of $\mathrm{XO}$ and hypoxanthine (data not shown).

Free radical scavengers. Neither 5 or $10 \mathrm{mM}$ DMSO nor 5 to $15 \mathrm{mM}$ DMTU decreased the loss of adenine nucleotides caused by $\mathrm{XO}$ and hypoxanthine or altered the leakage of nucleotides or catabolic products into the medium (data not shown).

Antioxidant vitamins. Neither $\alpha$-tocopherol nor ascorbic acid modified the adenine nucleotide depletion induced by hypoxanthine and XO (data not shown). To explore the long-term effects of $\alpha$-tocopherol, cells were cultured in the presence of 50 or 100 $\mu \mathrm{M}$ of the vitamin for $3 \mathrm{~d}$. No protective effect was obtained, inasmuch as after the exposure to hypoxanthine and XO unsupplemented cells contained $15 \pm 2 \%$ of total radioactivity in adenine nucleotides $(n=4)$ compared with $14 \pm 1 \%$ in cells supplemented with $50 \mu \mathrm{M}$ and $12 \pm 2 \%$ in cells supplemented with $100 \mu \mathrm{M} \alpha$-tocopherol. The distribution of radioactivity between the catabolic products and nucleotides in the medium was also unaltered.

$3-A B A$. When an inhibitor of poly-ADP-ribose polymerase, 3$\mathrm{ABA}$, was present in the culture well with $\mathrm{XO}$ and hypoxanthine, partial protection from nucleotide depletion was seen (Fig. 4). The effect was almost maximal at the lowest concentration studied.

\section{DISCUSSION}

The main by-product of the hypoxanthine/XO reaction is the superoxide anion, but some hydrogen peroxide is also generated. The superoxide radical is converted into the hydrogen peroxide by a dismutation reaction, and if ferrous iron is present, into the hydroxyl radical in an iron-catalyzed Fenton reaction (19). Evidence bearing on the role of these compounds in cell injury has usually been indirect, based on the effect of antioxidant enzymes or free radical scavengers in preventing damage. The results have been quite variable, depending on the experimental system and the method of assessing damage.

In our model, adenine nucleotide depletion may be due to intracellular catabolism and/or membrane damage, not necessarily lethal, resulting in leakage of intact nucleotides out of the cytoplasm. The exact contribution of these two mechanisms is difficult to estimate, because endothelial cells have active ectonucleotidases (18), which would catabolize extruded nucleotides and lead to underestimation of membrane leakage. Our previous findings, obtained by using an inhibitor of ecto-5'-nucleotidase. 


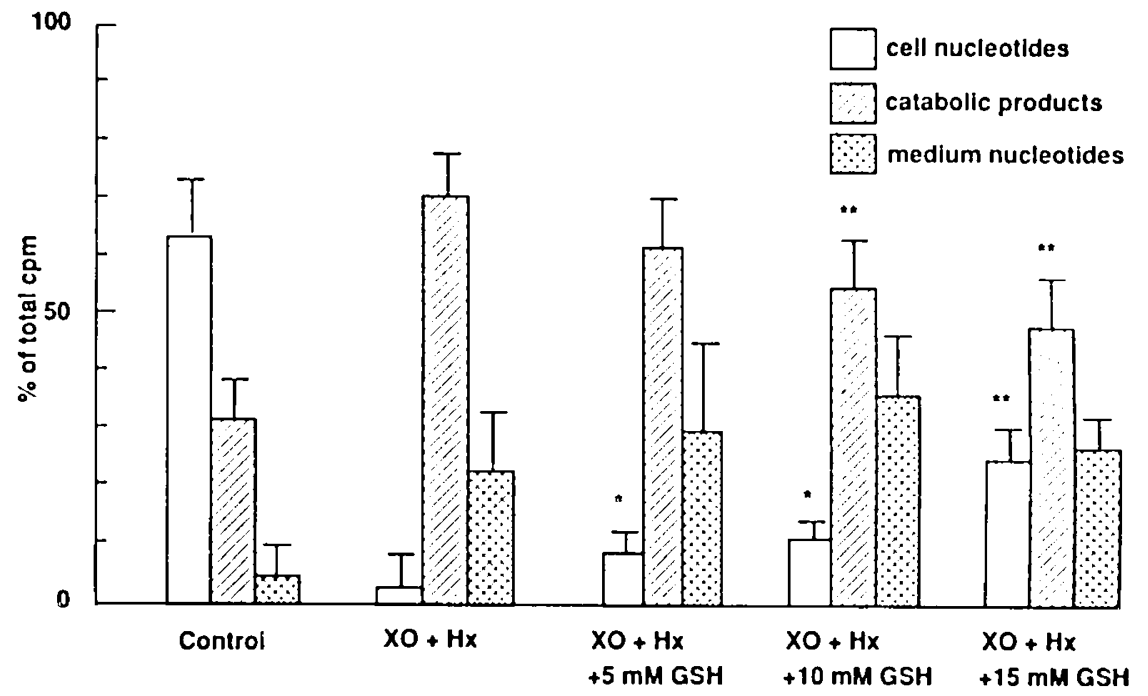

Fig. 1. Prevention of adenine nucleotide depletion by GSH. Endothelial cells were prelabeled with ${ }^{14} \mathrm{C}$-adenine, incubated $4 \mathrm{~h}$ with $80 \mathrm{mU} / \mathrm{mL}$ $\mathrm{XO}$ and $100 \mu \mathrm{M}$ hypoxanthine ( $/ \mathrm{x}$ ) (except control), with or without 5 or $15 \mathrm{mM}$ GSH. Results are expressed as \% of total soluble radioactivity in cells and medium. Open columms, cellular adenine nucleotides: hatched columm.s, sum of catabolic products (hypoxanthine, xanthine, and uric acid) in the medium; crosshatched collumns, sum of nucleotides in the medium. ${ }^{*}, p<0.05 ;^{* *}, p<0.01$ compared with XO + hypoxanthine group. Mann-Whitney U test, $n=4$.

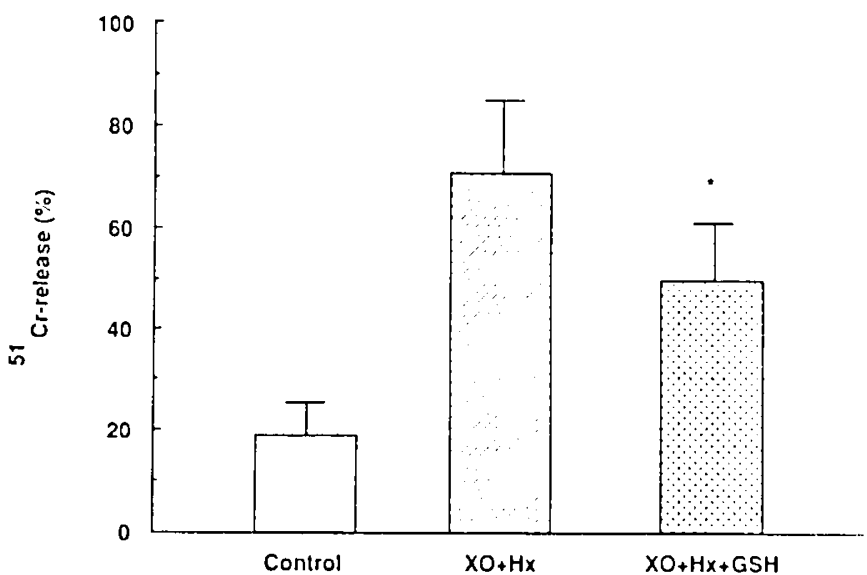

Fig. 2. ${ }^{\text {s1 }} \mathrm{Cr}$-release from endothelial cells and prevention by GSH. Cells prelabeled with ${ }^{\text {s1 }} \mathrm{Cr}$, incubated with $80 \mathrm{mU} / \mathrm{mL}$ XO and $100 \mu \mathrm{M}$ hypoxanthine $(/ / x)$ (except control cells) with or without GSH $(5 \mathrm{mM})$. Op'n collumn, control; hatched column, XO and hypoxanthine; crosshatched column, XO, hypoxanthine, and GSH. ${ }^{*}, p<0.05$ (MannWhitney $\mathrm{U}$ test, $n=4$ ).

indicate that a superoxide-generating system ( $\mathrm{XO}+$ hypoxanthine), but not hydrogen peroxide, causes membrane damage and leakage of nucleotides (20). We have also shown that depletion of prelabeled nucleotides corresponds very closely to measurements of total nucleotide levels by liquid chromatography (20). This rules out significant resynthesis of ATP during exposure to ROM.

$\mathrm{XO}$ activity in endothelial cells is unmeasurably low (15). Thus, our model reflects the effects of free radicals generated extracellularly by $\mathrm{XO}$ in the circulation $(10)$ or by granulocytes (11). We have also shown that exposure to the superoxidegenerating system decreases ecto-5'-nucleotidase activity of endothelial cells (21). This influences the pattern of metabolites in the extracellular fluid but not nucleotide depletion itself.

The concentration of $\mathrm{XO}$ used in this study is similar to levels reported locally in vivo $(9,10,22)$. We have studied the dose response to $\mathrm{XO}$ (without hypoxanthine) and found that $1 \mathrm{mU} /$ $\mathrm{mL}$ of XO causes a significant decrease in nucleotide levels in endothelial cells (15). Endogenous production of hypoxanthine was sufficient for a modest effect, but nucleotide depletion was increased by addition of exogenous hypoxanthine at concentrations encountered in clinical situations $(23,24)$.

GSH is known as an important component of the cellular defenses against free radical damage. Depletion of GSH aggravates $\mathrm{XO}$-xanthine-induced epithelial cell death and membrane damage, as assessed by the release of LDH from cells (25), and at concentrations from 2 to $5 \mathrm{mM}$ extracellular GSH protects endothelial cells from ATP depletion caused by hydrogen peroxide (26). We observed only partial but dose-dependent prevention of nucleotide depletion by GSH and very little effect on the leakage of nucleotides into the culture medium. GSH is poorly transported into endothelial cells $(26,27)$, and it may act as a scavenger of free radicals $(2,25)$. Thus, it is possible that the effects of glutathione in our experiments were extracellular. Protection of the ischemic kidney by i.v. GSH may be another example of extracellular effects of this compound (28).

In cultured fibroblasts and endothelial cells exposed to XO and acetaldehyde or hypoxanthine, CAT at concentrations from 250 to $1000 \mathrm{U} / \mathrm{mL}$ has been found more effective in preventing cell death, as assessed by release of ${ }^{51} \mathrm{Cr}$, than SOD at concentrations from 75 to $500 \mathrm{U} / \mathrm{mL}(12,29)$. In our experiments, both enzymes had only modest effect. which was entirely consistent with previous data. We have shown that XO plus hypoxanthine, but not hydrogen peroxide, causes a leakage of nucleotides from endothelial cells, whereas the latter compound induces catabolism of intracellular nucleotides (20). Accordingly, SOD modified nucleotide leakage, whereas CAT markedly decreased intracellular catabolism (Fig. 3). Failure of SOD to prevent catabolism may be caused by continued formation of hydrogen peroxide by dismutation and partly by $\mathrm{XO}$ itself.

In studies with trypan blue uptake or release of ${ }^{51} \mathrm{Cr}$ from prelabeled cells as the end point. CAT has been more protective, relatively speaking, than in our experiments $(5,12)$. This may be because nucleotide depletion is a more sensitive, but not necessarily irreversible, index of free radical effects (30). In this study, concentrations of the antioxidant enzymes SOD and CAT lower than $300 \mathrm{mU} / \mathrm{mL}$ did not protect the cell from injury due to ROM. Excessive concentrations, higher than $600 \mathrm{mU} / \mathrm{mL}$, could prevent damage because of the protective effect of any big protein molecule, similarly to albumin (31).

DMSO and DMTU are scavengers mainly of the hydroxyl radical $(12,32)$. They failed to prevent nucleotide depletion in 


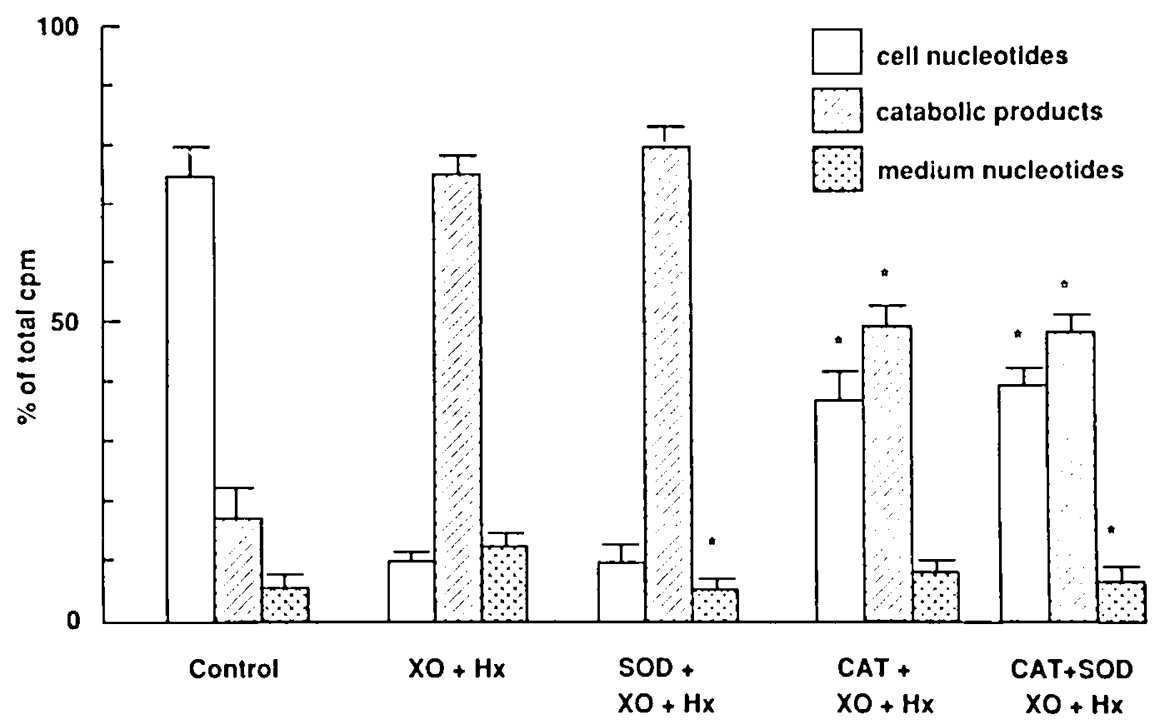

Fig. 3. Prevention of adenine nucleotide leakage to the medium with SOD, or prevention of nucleotide depletion by CAT and the combination of SOD and CAT. Prevention of nucleotide depletion or leakage from endothelial cells prelabeled with ${ }^{14} \mathrm{C}$-adenine for $4 \mathrm{~h}$ with or without $80 \mathrm{mU} /$ $\mathrm{mL} \mathrm{XO}$ and $100 \mu \mathrm{M}$ hypoxanthine $(I / x)$ with or without $600 \mathrm{IU} / \mathrm{mL}$ SOD or CAT as indicated. Expression of results and symbols are as in Figure 1.

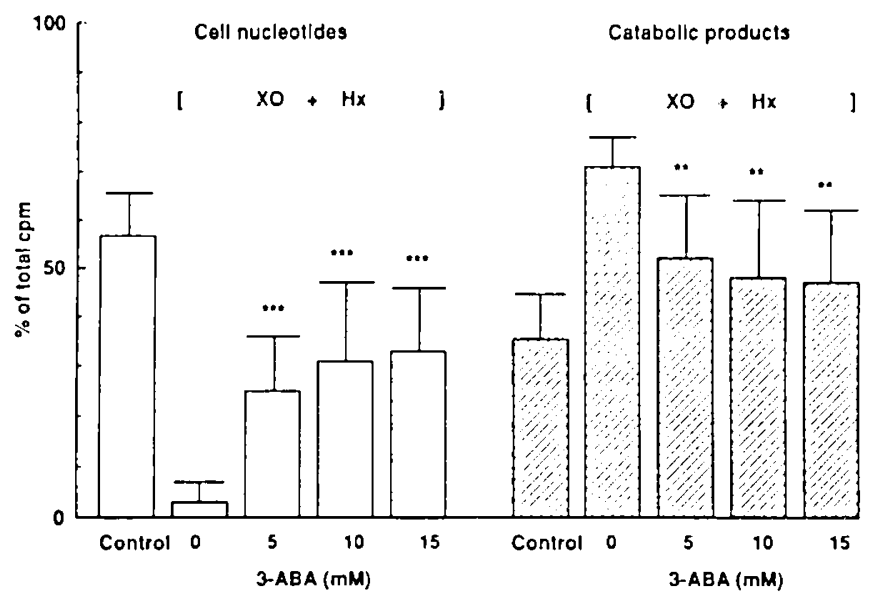

Fig. 4. Prevention of nucleotide depletion with $3-A B A$. Prelabeled cells (with ${ }^{14} \mathrm{C}$-adenine) were incubated with $80 \mathrm{mU} / \mathrm{mL}$ XO and 100 $\mu \mathrm{M}$ hypoxanthine $(H / x)$ as indicated (except control) with or without different concentrations of $3-\mathrm{ABA}$ as indicated. ${ }^{* *} . p<0.01,{ }^{* * *}, p<$ 0.001 compared with $\mathrm{XO}+$ hypoxanthine group (Mann-Whitney $\mathrm{U}$ test, $n=4)$.

our model at levels previously found to protect endothelial cells from injury induced by $\mathrm{XO}+$ hypoxanthine or hydrogen peroxide as assessed by ${ }^{51} \mathrm{Cr}$ or $\mathrm{LDH}$ release $(12,32)$. DMSO and DMTU protected mice against oxygen toxicity but they did not inhibit trichloroacetic acid induced lipid peroxidation in vitro at levels similar to those we have used (33). This suggests either that nucleotide depletion and endothelial cell death as assessed by ${ }^{51} \mathrm{Cr}$ or LDH release do not have a simple causal relationship or that the hydroxyl radical does not play a significant role under our experimental conditions. The endothelial cells used in our experiments were beyond the second passage. Their iron content may be lower than in uncultured endothelial cells (34). This implies lower production of the hydroxyl radical, which may explain the lack of effect of DMSO and DMTU. In other studies, DMTU has prevented cell death due to hydrogen peroxide (12, 35 ). The discrepancy with our results may again depend on the different criterion for assessment.

$\alpha$-Tocopherol exerts its antioxidant effect in biologic membranes $(2,34)$. Because it had no protective effect when present in the incubation medium together with $\mathrm{XO}$ and hypoxanthine, we attempted to "load" cell membranes by prolonged incubation with $\alpha$-tocopherol. However, nucleotide depletion was unaffected by this treatment. The explanation may be that under ordinary culture conditions there is sufficient antioxidant present for maximal effect (36), which cannot be augmented by an excess. We have previously demonstrated the protective effect of serum on ROM-induced injury (15), which was mainly attributable to albumin. The remaining approximate $20 \%$ of the effect was not characterized, but could be due to vitamin $\mathrm{C}$ or $\mathrm{E}$ or uric acid (37). The cells in that study, as well as in the present experiments, were grown in F-10 medium containing $20 \%$ human serum before the actual exposures. They may thus have been provided with ample antioxidant vitamins. We did not study the possible role of uric acid present in serum.

The enzyme poly-ADP-ribose polymerase is activated by DNA damage, promoting DNA repair but also depletion of NAD and ATP (38). Its inhibitor, 3-ABA, at a concentration of $2.5 \mathrm{mM}$, has been found to prevent ATP depletion (39) but was less effective in our experiments. Again, the problem may be the site of action. If membrane leakage contributes significantly to adenine nucleotide depletion, as indicated by our recent findings (20), an intracellularly acting compound, such as 3-ABA, could not have a major protective effect.

Most of the agents studied in the present experiments have been found more effective in preventing ROM-induced cell death when either unreasonably high concentrations or less sensitive indicators of irreversible damage have been used $(5,12,25)$. It seems that endothelial cells tolerate severe nucleotide depletion without necessarily losing their viability. A similar conclusion was reached in studies in which inhibition of energy metabolism was used to induce nucleotide depletion in endothelial cells (40). Functional disturbances preceding irreversible damage have previously been shown upon exposure of endothelial cells to hydrogen peroxide (41). Such disturbances, like nucleotide depletion used in our studies, may be too sensitive to provide optimal parameters for assessing cytoprotection. Nevertheless, a thorough in vitro evaluation is essential before the clinical use of potential antioxidant compounds is contemplated.

\section{REFERENCES}

1. McCord JM 1985 Oxygen-derived free radicals in postischemic tissue injury N Engl J Med 312:159-163

2. Southorn PA. Powis G 1988 Free radicals in medicine II. Involvement in human disease. Mayo Clin Proc 63:381-389 
3. Britigan BE, Pou S, Rosen GM, Lilleg DM, Buettner GR 1990 Hydroxyl radical is not a product of the reaction of xanthine oxidase and xanthine. $J$ Biol Chem 265:17533-17538

4. Parks DA. Williams TK. Beckman JS 1988 Conversion of xanthine dehydrogenase to oxidase in ischemic rat intestine: a reevaluation. Am J Physiol 254:G768-G774

5. Zweier JL, Kuppusamy P, Lutty GA 1988 Measurement of endothelial cell free radical generation: evidence for a central mechanism of free radical injury in postischemic tissues. Proc Natl Acad Sci USA 85:4046-4050

6. Saugstad OD 1990 Oxygen toxicity in the neonatal period. Acta Paediatr Scand 79:881-892

7. Frank L, Bucher JR, Roberts RJ 1978 Oxygen toxicity in neonatal and adult animals of various species. J Appl Physiol 45:699-704

8. Parks DA, Granger DN 1986 Xanthine oxidase: biochemistry, distribution and physiology. Acta Physiol Scand 548:87-99

9. Yokoyama Y. Beckman JS. Beckman TK. Wheat JK, Cash TG, Freeman BA. Parks DA 1990 Circulating xanthine oxidase: potential mediator of ischemic injury. Am J Physiol 258:G564-G570

10. Friedl HP. Smith DJ, Till GO, Thompson PD, Louis DS, Ward PA 1990 Ischemia-reperfusion in humans. Appearance of xanthine oxidase activity. Am J Pathol 136:491-495

11. Andreoli SP. Baehner RL. Bergstein JM 1985 In vitro detection of endothelial cell damage using 2-dcoxy-D- ${ }^{3} \mathrm{H}$-glucose: comparison with chromium $5 !$, ${ }^{3} \mathrm{H}$-leucine, ${ }^{3} \mathrm{H}$-adenine, and lactate dehydrogenase. J Lab Clin Med 106:253261

12. Kvietys PR, Inauen W, Bacon BR. Grisham MB 1989 Xanthine oxidaseinduced injury to endothelium: role of intracellular iron and hydroxyl radical Am J Physiol H1640-H!646

13. Grosso MA Brown JM, Viders DE, Mulvin DW, Banerjee A, Velasco SE Repine JE. Harken AH 1989 Xanthine oxidase-derived oxygen radicals induce pulmonary edema via direct endothelial cell injury. J Surg Res 46:355-360

14. Kistler GS, Caldwell PRB, Weibel ER 1967 Development of fine structural damage to alveolar and lining cells in oxygen-poisoned rat lungs. J Cell Biol 33:605-628

15. Aalto TK, Raivio KO 1990 Adenine nucleotide depletion from endothelial cells exposed to xanthine oxidase. Am J Physiol 259:C883-C888

16. Matsumoto SS, Raivio KO, Seegmiller JE 1979 Adenine nucleotide degradation during energy depletion in human lymphoblasts. J Biol Chem 254:89568962

17. Dixon WJ 1985 BMDP Statistical Software. University of California Press. Berkeley, CA

18. Gordon JL 1986 Extracellular ATP: effects, sources and fate. Biochem J 233:309-319

19. Halliwell B. Gutteridge JMC 1986 Oxvgen free radicals and iron in relation to biology and medicine: some problems and concepts. Arch Biochem Biophys 246:501-514

20. Aalto TK. Raivio KO 1993 Mechanisms of adenine nucleotide depletion from endothelial cells exposed to reactive oxygen metabolites. Free Radic Biol Med 14:177-183

21. Aalto TK. Raivio KO 1993 Metabolism of extracellular adenine nucleotides and adenosine by human endothelial cells exposed to reactive oxygen metabolites. Am J Physiol 264:C282-C286
22. Punch J, Rees R, Cashmer B. Wilkins E. Smith DJ. Till GO 1992 Xanthine oxidase: its role in the no-reflow phenomenon. Surgery 111:169-176

23. Harkness RA 1988 Hypoxanthinc, xanthine and uridine in body fluids, indicators of ATP depletion. J Chromatogr 429:255-278

24. Ruth V. Fyhrquist F. Clemons G. Raivio KO 1988 Cord plasma vasopressin. erythropoietin. and hypoxanthine as indices of asphyxia at birth. Pediatr Res 24:490-494

25. Olson CE 1988 Glutathione modulates toxic oxvgen metabolite injury of canine cell monolayers in primary culture. Am J Physiol 254:G49-G56

26. Chang MY. Ming S, Forman HJ 1992 Exogenous glutathione protects endothelial cells from menadione toxicity. Am J Physiol 262:L637-L643

27. Puri RN, Meister A 1983 Transport of glutathione, as gamma-glutamylcysteinylglycyl ester, into liver and kidney. Proc Natl Acad Sci USA 80:52585260

28. Paller MS, Sikora JJ 1988 Renal work, glutathione and susceptibility to frec radical-mediated postischemic injury. Kidney Int 33:843-849

29. Simon RH, Scoggin CH, Patterson D 1981 Hydrogen peroxide causes the fatal injury to human fibroblasts exposed to oxygen radicals. J Biol Chem 256:718!-7186

30. Hinshaw DB. Armstrong BC. Beals TF, Hyslop PA 1988 A cellular model of endothelial cell ischemia. J Surg Res 44:527-537

31. Halliwell B. Gutteridge JMC 1990 The antioxidants of human extracellular fluids. Arch Biochem Biophys 280:1-8

32. Toth KM. Harlan JM, Beehler CJ, Berger EM, Parker NB, Linas SL, Repine JE 1989 Dimethylthiourea prevents hydrogen peroxide and neutrophil mediated damage to lung endothelial cells in vitro and disappears in the process. Free Radic Biol Med 6:457-466

33. Lin YG, Jamieson D 1992 Effects of antioxidants on oxygen toxicity in vivo and lipid peroxidation in vitro. Pharmacol Toxicol 70:271-277

34. Varani J, Dame MK, Gibbs DF, Taylor CG, Weinberg JM, Shayevitz J, Ward PA 1992 Human umbilical vein endothelial cell killing by activated neutrophils. Lab Invest $66: 708-714$

35. Massey KD, Burton KP 1989 Alpha-tocopherol attenuates myocardial membrane-related alterations resulting from ischemia and reperfusion. Am J Physiol 256:H1192-H1199

36. Huang $N$, Lineberger B, Steiner M 1988 Alpha-tocopherol, a potent modulator of endothelial cell function. Thromb Res 50:547-557

37. Wayner DDM, Burton GW, Ingold KU, Barclay LRC, Locke SJ 1987 The relative contributions of vitamin $\mathrm{E}$, urate, ascorbate and proteins to the total peroxyl radical-trapping antioxidant activity of human blood plasma. Biochim Biophys Acta 924:408-419

38. Schraufstatter IU, Hyslop PA. Hinshaw DB, Spragg RG, Sklar LA, Cochrane CG 1986 Hydrogen peroxide-induced injury of cells and its prevention by inhibitors of poly (ADP-ribose) polymerase. Proc Natl Acad Sci USA $83: 4908-4912$

39. Schraufstatter IU, Hinshaw DB, Hyslop PA, Spragg RG, Cochrane CG 1986 Oxidant injury of cells. DNA strand-breaks activate polyadenosine diphosphate-ribose polymerase and lead to depletion of nicotinamide adenine dinucleotide. J Clin Invest 77:1312-1320

40. Watanabe H. Kuhne W, Spahr R, Schwartz P. Piper liM I991 Macromolecule permeability of coronary and aortic endothelial monolayers under energy depletion. Am J Physiol 260:H1344-H1352

41. Ager A. Gordon JL 1984 Differential effects of hydrogen peroxide on indices of endothelial cell function. J Exp Med 159:592-603 